Buletin Ilmiah Math. Stat. dan Terapan (Bimaster)

Volume 08, No. 1 (2019), Hal 83-90.

\title{
MODEL AUTOREGRESSIVE DISTRIBUTED LAG (ADL) PADA DATA HARGA SAHAM
}

\author{
Uny Minna Chilin, Evy Sulistianingsih, Naomi Nessyana Debataraja
}

INTISARI

\begin{abstract}
Harga saham adalah sejumlah nilai dalam mata uang rupiah yang terbentuk berdasarkan penawaran jual dan permintaan beli efek yang dilakukan oleh anggota Bursa Efek di Bursa Efek Indonesia (BEI). PT. AKR Corporindo Tbk adalah salah satu perusahaan swasta terbesar di Indonesia yang mendistribusikan dan memperdagangkan bahan bakar dan bahan kimia dasar. Penelitian ini bertujuan untuk mengetahui pengaruh data IHSG dan kurs US Dollar terhadap harga saham dari PT. AKR Corporindo Tbk dengan menggunakan model Autoregressive Distributed Lag. Data yang digunakan merupakan data sekunder periode Januari 2011 sampai dengan Desember 2016. Model Autoregressive Distributed Lag (ADL) adalah model regresi yang memasukkan nilai variabel yang menjelaskan baik nilai masa kini atau nilai masa lalu (lag) dari variabel independen sebagai tambahan pada model yang memasukkan nilai lag dari variabel dependen sebagai salah satu variabel penjelas. Dari hasil pengujian, tidak terdapat kointegrasi antar variabel dependen dengan independen. Hasil estimasi parameter pada model ADL menunjukkan bahwa variabel yang berpengaruh signifikan terhadap harga saham PT. AKR Corporindo Tbk bulan sekarang adalah harga saham itu sendiri pada satu bulan sebelumnya dan IHSG pada bulan sekarang.
\end{abstract}

Kata Kunci: Kointegrasi, Autoregressive Distributed Lag (ADL).

\section{PENDAHULUAN}

Saham merupakan tanda penyertaan atau kepemilikan seseorang dalam suatu perusahaan. Selembar saham adalah selembar kertas yang menerangkan bahwa pemilik kertas tersebut adalah pemilik saham (berapa pun porsinya/jumlahnya) dari suatu perusahaan yang menerbitkan kertas (saham) tersebut. Saham merupakan alternatif investasi pada saat ini. Selembar kertas saham mempunyai nilai atau harga. Harga saham adalah sejumlah nilai dalam mata uang rupiah yang terbentuk berdasarkan penawaran jual dan permintaan beli efek yang dilakukan oleh anggota Bursa Efek di Bursa. Harga yang setiap hari diumumkan disurat kabar atau media lain adalah harga pasar yang tercatat pada waktu penutupan (close price) aktivitas di Bursa Efek Indonesia (BEI) [1].

Dalam dunia ekonomi, dikenal juga data runtun waktu (time series) yang diduga memiliki karakteristik tertentu, sehingga nilainya berfluktuasi. Sebagai contoh adalah harga saham suatu perusahaan atau Indeks Harga Saham Gabungan (IHSG) di pasar modal. Harga saham berfluktuasi setiap hari dan para pengamat meyakini bahwa fluktuasi harga saham ini dipengaruhi oleh berbagai faktor di luar pasar saham. Namun di sisi lain, ada juga pengamat yang berpendapat bahwa harga saham pada hari ini dipengaruhi oleh harga saham pada hari kemarin atau pada hari-hari sebelum kemarin. Data seperti ini biasanya dikumpulkan dalam sebuah interval periode yang regular, seperti harian, mingguan, bulanan, kuartalan dan tahunan [2].

Pada beberapa kasus tertentu, data time series tidak hanya dipengaruhi oleh data sebelumnya, tetapi juga dipengaruhi oleh data variabel lain yang juga memiliki data periode sekarang dan sebelumnya. Oleh karena itu, penelitian ini menganalisis data harga saham dari PT. AKR Corporindo Tbk yang diduga dipengaruhi oleh harga saham perusahaan itu sendiri pada periode sebelumnya serta IHSG dan kurs mata uang US Dollar. Untuk kasus seperti ini, maka model Autoregressive Distributed Lag (ADL) dapat digunakan. Model ADL dapat digunakan jika variabel dependen pada waktu $t\left(Y_{t}\right)$ dan variabel independen pada waktu $t\left(X_{t}\right)$ keduanya tidak stasioner namun tidak berkointegrasi [3]. 
Model ADL adalah model regresi yang memasukkan nilai variabel yang menjelaskan baik nilai masa kini atau nilai masa lalu (lag) dari variabel independen sebagai tambahan pada model yang memasukkan nilai lag dari variabel dependen sebagai salah satu variabel penjelas [4]. Model ADL, digunakan secara luas dalam analisis ekonometrik. Model ini dapat membedakan respon jangka pendek dan jangka panjang dari variabel dependen terhadap satu unit perubahan dalam nilai variabel independen. Tujuan pada penelitian ini adalah melakukan estimasi parameter model ADL pada data harga saham PT. AKR Corporindo Tbk, IHSG dan kurs US Dollar dari periode Januari 2011 sampai dengan Desember 2016.

\section{UJI KOINTEGRASI}

Kointegrasi merupakan kombinasi hubungan linear dari variabel-variabel yang nonstasioner dan semua variabel harus terintegrasi pada orde atau derajat yang sama. Uji kointegrasi dipopulerkan oleh Engle dan Granger pada tahun 1987. Uji ini dilakukan untuk menganalisis hubungan jangka panjang antara variabel-variabel independen dengan variabel dependen, terutama pada model yang mengandung variabel-variabel yang tidak stasioner [4]. Uji ini juga dilakukan untuk mengetahui kemungkinan terjadi keseimbangan jangka panjang antar variabel-variabel yang di amati. Uji kointegrasi Engle-Granger yang langkah-langkahnya secara singkat diberikan berikut ini [3]:

1. Melakukan uji adanya unit root dalam variabel $Y_{t}$ dan $X_{t}$ (misal menggunakan uji Augmanted

Dickey-Fuller atau ADF). Orde unit root ini harus sama dan bernilai $d$. Jika hipotesis adanya unit root ditolak, maka hipotesis adanya kointegrasi antarvariabel akan ditolak.

2. Selanjutnya, dilakukan estimasi persamaan regresi antara $Y_{t}$ dan $X_{t}$ (atau secara umum, antara $Y_{t}$ dan $\left.X_{t 1}, X_{t 2}, \ldots, X_{t k}\right)$ dan simpan residual dari regresi ini $\left(e_{t}\right)$.

3. Langkah uji unit root terhadap residual $e_{t}$ yang diperoleh dari langkah 2. Jika hipotesis adanya unit root ditolak, maka disimpulkan $Y_{t}$ dan $X_{t}$ berkointegrasi (atau secara umum $Y_{t}$ dan $X_{t 1}, X_{t 2}, \ldots, X_{t k}$ berkointegrasi).

Jika variabel-variabel dalam regresi linear, baik variabel dependen maupun variabel independen memiliki akar unit, biasanya eror juga mengandung akar unit. Pada keadaan ini muncul regresi lancung. Namun, sering ditemukan bahwa eror tidak mengandung trend meskipun variabel dependen maupun variabel independen mengandung trend. Keadaan seperti ini sering disebut sebagai kasus variabel dependen berkointegrasi dengan variabel independen. Dengan demikian, jika terjadi kointegrasi masalah regresi lancung akan hilang. Dalam keadaan dimana variabel dependen dan independen tidak stasioner namun berkointegrasi, maka model yang cocok digunakan adalah Error Correction Model (ECM).

\section{PENENTUAN PANJANG LAG}

Untuk menentukan panjang lag dari $Y_{t}$ dan $X_{t}$ dapat menggunakan metode dari Alt dan Tinbergen yang menyarankan prosedur sekuensial (berurutan) untuk mendapatkan panjang lag dari model $\operatorname{ADL}(p, q)$, yaitu pertama meregresikan $Y_{t}$ pada $X_{t}$ kemudian meregresikan $Y_{t}$ pada $X_{t}$ dan $X_{t-1}$, meregresikan $Y_{t}$ pada $X_{t}, X_{t-1}$ dan $X_{t-2}$, dan seterusnya. Prosedur sekuensial berhenti bila koefisien regresi dari variabel lag mulai menjadi tidak signifikan secara statistik atau koefisien dari paling tidak satu variabel berubah tanda dari positif ke negatif atau sebaliknya [5].

\section{MODEL AUTOREGRESSIVE DISTRIBUTED LAG (ADL)}

Model regresi linear yang sering ditemui biasanya tidak memperhatikan pengaruh waktu, karena pada umumnya model regresi linear cenderung mengasumsikan bahwa pengaruh variabel independen 
terhadap variabel dependen terjadi dalam kurun waktu yang sama. Namun, dalam model regresi linear juga terdapat model regresi yang memperhatikan pengaruh waktu. Waktu yang diperlukan bagi variabel independen $X$ dalam mempengaruhi variabel dependen $Y$ disebut bedakala (lag).

Model regresi yang memasukkan nilai variabel yang menjelaskan baik nilai masa kini atau nilai masa lalu (lag) dari variabel independen sebagai tambahan pada model yang memasukkan nilai lag dari variabel dependen sebagai salah satu variabel penjelas disebut Autoregressive Distributed Lag (ADL). Model ini dapat membedakan respon jangka pendek dan jangka panjang dari variabel dependen terhadap satu unit perubahan dalam nilai variabel independen [4]. Model ADL dapat dinyatakan sebagai berikut:

$$
Y_{t}=\alpha+\phi_{1} Y_{t-1}+\cdots+\phi_{p} Y_{t-p}+\beta_{0} X_{t}+\beta_{1} X_{t-1}+\cdots+\beta_{q} X_{t-q}+\varepsilon_{t}
$$

dimana $Y_{t}$ adalah variabel dependen, $X_{t}$ adalah variabel independen, $\alpha$ adalah konstanta, $\phi_{p}$ adalah parameter untuk model autoregressive, $\beta_{q}$ adalah parameter untuk model distributed lag dan $\varepsilon_{t}$ adalah nilai error. Pada keadaan dimana $Y_{t}$ dan $X_{t}$ tidak stasioner tetapi berkointegrasi, maka model yang cocok digunakan adalah Error Correction Model (ECM). Namun, jika keadaan dimana $Y_{t}$ dan $X_{t}$ tidak stasioner dan juga tidak berkointegrasi, maka model yang cocok digunakan adalah model ADL. Model ADL untuk keadaan $Y_{t}$ dan $X_{t}$ yang tidak stasioner dan tidak berkointegrasi dapat ditulis sebagai berikut:

$$
\Delta Y_{t}=\alpha+\phi_{1} \Delta Y_{t-1}+\cdots+\phi_{p} Y_{t-p}+\beta_{0} \Delta X_{t}+\beta_{1} \Delta X_{t-1}+\cdots+\beta_{q} \Delta X_{t-q}+\varepsilon_{t}
$$

dengan $\Delta$ adalah pembedaan (difference) [3].

\section{MODEL AUTOREGRESSIVE DISTRIBUTED LAG PADA HARGA SAHAM}

\section{Data}

Data dalam penelitian ini berupa data harga saham PT. AKR Corporindo Tbk sebagai variabel dependen, serta US Dollar dan IHSG sebagai variabel independen. Data yang diperoleh dari www.finance.yahoo.com ini merupakan data sekunder. Dimana $Y_{1}, Y_{2}, Y_{3}, \ldots, Y_{72}$ adalah data harga saham, $X_{11}, X_{12}, X_{13}, \ldots, X_{172}$ adalah data IHSG, sedangkan $X_{21}, X_{22}, X_{23}, \ldots, X_{272}$ adalah data kurs US Dollar. PT. AKR Corporindo Tbk adalah sebuah penyedia jasa untuk solusi rantai suplai yang terintegrasi. Perusahaan ini adalah salah satu perusahaan swasta terbesar di Indonesia yang mendistribusikan dan memperdagangkan bahan bakar dan bahan kimia dasar. Perusahaan ini juga bergerak di bidang jasa logistik, dan manufaktur sorbitol dan juga bahan-bahan perekat. Data dalam penelitian ini merupakan data bulanan dari Januari 2011 sampai dengan Desember 2016. Grafik data harga saham PT. AKR Corporindo Tbk, IHSG dan kurs US Dollar dari Januari 2011 sampai dengan Desember 2016 disajikan pada Gambar 1.

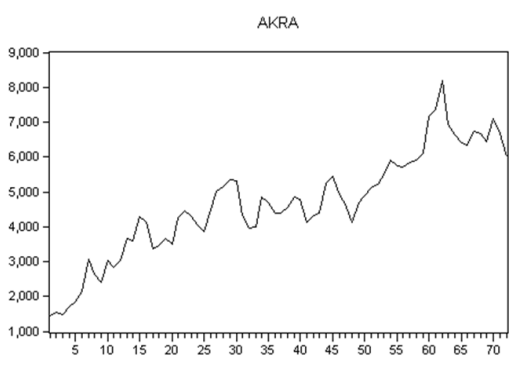

(a) Harga Saham

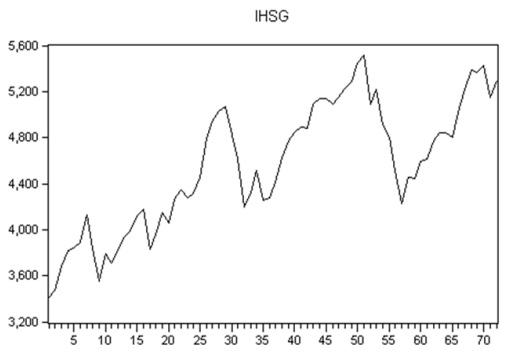

(b) IHSG 


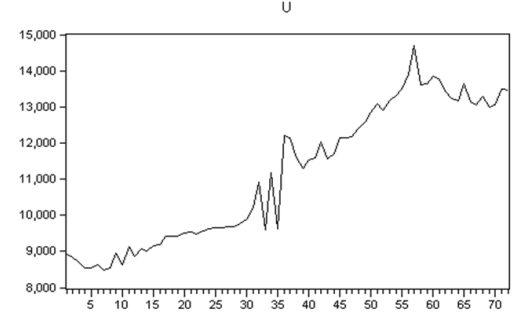

(c) US Dollar

\section{Gambar 1.Grafik Data Harga Saham, IHSG dan Kurs US Dollar}

\section{Uji Stasioneritas}

Dari Gambar 1, terlihat bahwa data mengandung unsur trend, maka dapat dikatakan bahwa data tidak stasioner dalam varian dan rata-rata. Untuk lebih meyakinkan hasil tersebut dapat dilihat dari nilai lambda $(\lambda)$ dengan metode transformasi Box-Cox dan uji Augmented Dickey Fuller (ADF) pada setiap data. Metode transformasi Box-Cox digunakan untuk menguji stasioneritas dalam varian, yaitu diperoleh nilai $\lambda$ masing-masing variabel harga saham, IHSG dan US Dollar sebesar 0,50, 1,00 dan 0,00 . Karena nilai $\lambda$ dari variabel IHSG telah bernilai 1 , maka dapat disimpulkan variabel IHSG tidak perlu dilakukan transformasi. Sedangkan, nilai $\lambda$ dari variabel harga saham dan US Dollar masih belum mendekati 1, maka dapat disimpulkan variabel harga saham dan US Dollar perlu dilakukan transformai Box-Cox. Jenis transformasi yang digunakan untuk variabel harga saham dan US Dollar, yaitu $\sqrt{X}$ dan $\operatorname{Ln}(X)$. Setelah variabel harga saham dan US Dollar ditransformasi, dihasilkan variabel harga saham, IHSG dan US Dollar telah stasioner dalam varian.

Pada uji stasioneritas dalam rata-rata dapat dilakukan dengan uji ADF. Hipotesis uji yang digunakan sebagai berikut:

$\mathrm{H}_{0}$ : terdapat unit root atau data tidak stasioner

$\mathrm{H}_{1}$ : tidak terdapat unit root atau data stasioner

Hipotesis nol ditolak jika nilai statistik uji ADF memiliki nilai kurang (lebih negatif) dibandingkan nilai daerah kritis $5 \%$ atau $p$-value $<5 \%$ yang berarti data tidak terdapat unit root atau data stasioner, dan sebaliknya terima hipotesis nol jika nilai statistik uji ADF lebih besar dari nilai daerah kritis 5\% atau $p$-value $>5 \%$ yang berarti data terdapat unit root atau data tidak stasioner. Hasil uji ADF yang diperoleh, yaitu nilai statistik uji ADF dari variabel AKRA, IHSG dan LnUSD masing-masing sebesar $-2,9211,-1,8503$ dan $-0,6270$. Nilai daerah kritis $5 \%$ yang diperoleh masing-masing variabel sebesar $-2,9055,-2,9029$ dan $-2,9035$, karena nilai statistik uji ADF dari variabel AKRA kurang dari (lebih negatif) dari nilai daerah kritis $5 \%$ maka disimpulkan tolak $\mathrm{H}_{0}$ yang berarti variabel AKRA telah stasioner. Sedangkan, nilai uji ADF dari variabel IHSG dan LnUSD lebih besar dari nilai daerah kritis 5\% maka disimpulkan terima $\mathrm{H}_{0}$ yang berarti variabel IHSG dan LnUSD belum stasioner. Oleh karena itu, perlu dilakukan proses difference orde pertama (first difference) untuk data yang belum stasioner. Hasil first difference disajikan pada Tabel 1.

Tabel 1. Hasil Uji ADF Pada First Difference

\begin{tabular}{|c|c|c|c|c|}
\hline \multirow[b]{2}{*}{ Variabel } & \multirow[b]{2}{*}{ ADF Statistic } & Nilai Kritis & \multirow[b]{2}{*}{$P$-value } & \multirow{2}{*}{ Kesimpulan } \\
\hline & & $5 \%$ & & \\
\hline AKRA & $-2,921166$ & $-2,905519$ & 0,0482 & Stasioner \\
\hline DIHSG & $-7,773487$ & $-2,903566$ & 0,0000 & Stasioner \\
\hline DLnUSD & $-16,78653$ & $-2,903566$ & 0,0001 & Stasioner \\
\hline
\end{tabular}


Model Autoregressive Distributed Lag (ADL) pada Data Harga Saham

Dari ADF Statistic dan p-value dari kedua variabel pada Tabel 2 terlihat bahwa, IHSG dan LnUSD telah stasioner pada proses tingkat first difference dengan nilai statistik uji ADF yang lebih negatifdibandingkan nilai kritis $5 \%$ serta $p$-value $<5 \%$. Jadi, dapat disimpulkan tolak $\mathrm{H}_{0}$ yang berarti data telah stasioner.

\section{Uji Kointegrasi}

Uji kointegrasi dengan metode uji Engle-Granger digunakan untuk mengetahui ada tidaknya hubungan jangka panjang antar variabel-variabel independen dengan variabel dependen. Hipoteis uji yang digunakan adalah:

$\mathrm{H}_{0}$ : terdapat kointegrasi atau memiliki orde unit root sama

$\mathrm{H}_{1}$ :tidak terdapat kointegrasi atau memiliki orde unit root berbeda

Berdasarkan hasil uji stasioneritas data pada varian dan rata-rata, diketahui bahwa variabel AKRA telah stasioner pada level data, sehingga AKRA memiliki orde integrasi 0 atau I(0). Sedangkan, variabel IHSG dan LnUSD stasioner pada tingkat first difference, maka dapat dikatakan memiliki orde integrasi 1 atau I(1). Dari yang diketahui pada metode Engle-Granger langkah 1 menyatakan bahwa jika variabel-variabel tersebut harus memiliki orde unit root yang sama, maka terdapat kointegrasi antar variabel. Jika tidak sama, berarti tidak terdapat kointegrasi antar variabel. Karena variabel harga saham, IHSG dan kurs US Dollar tidak memiliki orde yang sama, maka dapat disimpulkan tolak $\mathrm{H}_{0}$ yang artinya tidak terdapat kointegrasi. Dengan demikian, model ADL cocok digunakan dalam penelitian ini.

\section{Penentuan Panjang Lag}

Penentuan panjang lag pada penelitian ini dilakukan dengan menerapkan metode Alt dan Tinbergen. Penerapan metode ini dilakukan dengan meregresikan variabel AKRA terhadap variabel AKRA satu bulan sebelumnya, lalu dilanjutkan dengan dua bulan sebelumnya hingga koefisien tanda berubah dari negatif ke positif atau sebaliknya. Penerapan metode ini dapat dilihat sebagai berikut:

$\mathrm{AKRA}_{\mathrm{t}}=5,7492+0,9224 \mathrm{AKRA}_{\mathrm{t}-1}$

AKRA $_{t}=6,0443+0,9316$ AKRA $_{t-1}-0,0133$ AKRA $_{t-2}$

Setelah dilakukan regresi linear pada masing-masing variabel, maka tanda dari masing-masing koefisien variabel diringkas pada Tabel 2.

Tabel 2. Penentuan Panjang Lag Masing-Masing Variabel

\begin{tabular}{cccc}
\hline Lag & AKRA & DIHSG & DLnUSD \\
\hline 0 & - & Positif & Positif \\
1 & Positif & Positif & Negatif* \\
2 & Negatif* & Positif & - \\
3 & - & Positif & - \\
4 & - & Negatif* & - \\
\hline
\end{tabular}

Pada lag 0 semua koefisien dari variabel DIHSG dan DLnUSD bernilai positif. Kemudian, lag diteruskan hingga lag 1 dan terdapat perubahan tanda pada koefisien variabel DLnUSD. Pada lag 2 terdapat perubahan tanda koefisien dari positif ke negatif pada variabel AKRA. Selanjutnya, terdapat perubahan tanda koefisien dari variabel DIHSG di lag 4. Dengan demikian, diperoleh maksimal lag untuk masing-masing variabel adalah variabel AKRA mempunyai lag 2, variabel DIHSG mempunyai maksimal lag 4 dan variabel DLnUSD mempunyai maksimal lag 1. 


\section{Estimasi Parameter}

Estimasi parameter model ini dilakukan dengan metode OLS untuk memperoleh model ADL. Hasil pendugaan parameter untuk model ADL dapat disajikan pada Tabel 3.

Tabel 3. Hasil Pendugaan Parameter Model ADL

\begin{tabular}{cccc}
\hline Variabel & Koefisien & $t$-statistic & $P$-value \\
\hline C & 6,716872 & 2,594805 & 0,0120 \\
AKRA(-1) & 0,887301 & 6,605653 & 0,0000 \\
AKRA(-2) & 0,022631 & 0,175679 & 0,8612 \\
DIHSG & 0,007669 & 3,492108 & 0,0009 \\
DIHSG(-1) & 0,002333 & 0,956195 & 0,3430 \\
DIHSG(-2) & $-0,001904$ & $-0,905039$ & 0,3693 \\
DIHSG(-3) & $-0,000317$ & $-0,147264$ & 0,8834 \\
DIHSG(-4) & $-0,003058$ & $-1,429328$ & 0,1584 \\
DLNUSD & $-3,948289$ & $-0,373742$ & 0,7100 \\
DLNUSD(-1) & $-6,287008$ & $-0,609381$ & 0,5447
\end{tabular}

Dari Tabel 3 hasil pendugaan model ADL dapat dituliskan sebagai berikut:

$\mathrm{AKRA}_{\mathrm{t}}=6,716+0,887 \mathrm{AKRA}_{\mathrm{t}-1}+0,022 \mathrm{AKRA}_{\mathrm{t}-2}+0,007 \mathrm{DIHSG}_{\mathrm{t}}+0,002 \mathrm{DIHSG}_{\mathrm{t}-1}-0,001 \mathrm{DIHSG}_{\mathrm{t}-2}$

$$
-0,0003 \text { DIHSG }_{\mathrm{t}-3}-0,003 \text { DIHSG }_{\mathrm{t}-4}-3,948 \operatorname{DLnUSD}_{\mathrm{t}}-6,287 \mathrm{DLnUSD}_{\mathrm{t}-1}+\varepsilon_{t}
$$

Setelah diperoleh pendugaan parameter, maka selanjutnya dilakukan estimasi parameter dan pengujian parameter-parameter yang signifikan dengan tingkat kepercayaan 5\%. Hasil estimasi parameter dapat disajikan pada Tabel 4.

Tabel 4. Hasil Estimasi Parameter

\begin{tabular}{lccc}
\hline \multicolumn{1}{c}{ Variabel } & Koefisien & t-statistic & $P$-value \\
\hline C & 4,288013 & 2,140107 & 0,0359 \\
AKRA $_{\mathrm{t}-1}$ & 0,941043 & 32,06616 & 0,0000 \\
DIHSG $_{\mathrm{t}}$ & 0,008194 & 4,137611 & 0,0001 \\
& & & \\
\hline
\end{tabular}

Ada dua macam pengujian parameter yaitu, uji parameter simultan (Uji F) dan uji parsial (Uji T). Pada Uji F, diperoleh dari hasil estimasi nilai $\mathrm{F}_{\text {hit }}$ sebesar 514,418 dan $p$-value sebesar 0,00000. Karena nilai $\mathrm{F}_{\text {hit }}>\mathrm{F}_{\text {tabel }}$ atau $p$-value $<5 \%$, maka dapat disimpulkan bahwa variabel independen secara bersamasama telah berpengaruh signifikan terhadap variabel dependen. Untuk Uji T, dapat dilihat pada $p$-value dari masing-masing variabel yang diperoleh pada Tabel 4, yaitu kurang dari $\alpha=5 \%$. Karena masingmasing variabel $p$-value $<5 \%$, maka dapat disimpulkan variabel independen secara parsial atau individu berpengaruh signifikan terhadap variabel dependen.

Dengan tingkat kepercayaan 95\% didapatkan hasil variabel-variabel yang memberikan kontribusi secara signifikan terhadap variabel dependen adalah $\mathrm{AKRA}_{\mathrm{t}-1}$ dan $\mathrm{DIHSG}_{\mathrm{t}}$. Dengan demikian, diperoleh model ADL sebagai berikut:

$$
\mathrm{AKRA}_{\mathrm{t}}=4,2880+0,9410 \mathrm{AKRA}_{\mathrm{t}-1}+0,0081 \mathrm{DIHSG}_{\mathrm{t}}+\varepsilon_{t}
$$

dengan nilai parameter $\alpha=4,2880, \phi_{1}=0,9410$ dan $\beta_{0}=0,0081$. Berdasarkan nilai adjusted $R^{2}$ yang diperoleh sebesar 0,9361 yang berarti variabel $\mathrm{AKRA}_{\mathrm{t}-1}$ dan $\mathrm{DIHSG}_{\mathrm{t}}$ akan menjelaskan variabel $\mathrm{AKRA}_{t}$ sebesar $93,61 \%$ dan sisanya $6,39 \%$ dijelaskan oleh variabel lain yang tidak termasuk dalam model melalui hubungan linear. 


\section{Uji Asumsi Klasik}

Model dikatakan baik digunakan jika memenuhi beberapa asumsi klasik yaitu, non-autokorelasi, non-heteroskedastisitas, residual berdistribusi normal dan non-multikolinearitas pada model terpenuhi. Berikut adalah hasil uji dari asumsi-asumsi tersebut.

a. Uji Normalitas

Uji normalitas residual dilakukan untuk melihat kenormalan dari residual. Dengan pengujian hipotesis sebagai berikut:

$\mathrm{H}_{0}$ : Residual berdistribusi normal

$\mathrm{H}_{1}$ : Residual tidak berdistribusi normal

Pengujian normalitas dilakukan dengan menggunakan uji Kolmogorov-Smirnov. Diperoleh hasil nilai signifikan dari uji Kolmogorov-Smirnov sebesar 0,570 yang lebih dari tingkat signifikan $\alpha=5 \%$. Dengan demikian, terima $\mathrm{H}_{0}$ sehingga residual dari model regresi berdistribusi normal.

b. Uji Autokorelasi

Untuk melakukan pengujian adanya autokorelasi residual, dilakukan uji hipotesis dengan pengujian hipotesis berikut:

$\mathrm{H}_{0}$ : Tidak terdapat korelasi serial pada residual

$\mathrm{H}_{1}$ : Terdapat korelasi serial pada residual

Output hasil uji autokorelasi dengan uji BGLM disajikan pada Tabel 5.

\section{Tabel 5. Ouput Uji Autokorelasi}

Breusch-Godfrey Serial Correlation LM Test:

\begin{tabular}{llll}
\hline \hline F-statistic & 0.016967 & Prob. F(2,66) & 0.9832 \\
Obs*R-squared & 0.036485 & Prob. Chi-Square(2) & 0.9819 \\
\hline \hline
\end{tabular}

Pada Tabel 5 terlihat nilai Prob Chi-Square(2) yang merupakan nilai p-value dari uji BGLM, yaitu sebesar 0,9819 dimana lebih dari 0,05. Dengan demikian, terima $\mathrm{H}_{0}$ yang berarti tidak terdapat masalah autokorelasi pada model.

c. Uji Heteroskedastisitas

Uji heteroskedastisitas atau uji homoskedastisitas bertujuan untuk mengetahui apakah varian dari residual bersifat konstan atau berubah-ubah. Jika residualnya mempunyai varian yang konstan, maka model tersebut dapat dikatakan baik. Untuk uji hipotesis ini adalah sebagai berikut:

$\mathrm{H}_{0}$ : Asumsi homokedastisitas terpenuhi

$\mathrm{H}_{1}$ : Asumsi homokedastisitas tidak terpenuhi

Output hasil pengujian dengan uji White disajikan pada Tabel 6.

Tabel 6. Output Uji Heteroskedastisitas

Heteroskedasticity Test: White

\begin{tabular}{llll}
\hline \hline F-statistic & 0.942151 & Prob. F(5,65) & 0.4599 \\
Obs*R-squared & 4.797879 & Prob. Chi-Square(5) & 0.4410 \\
Scaled explained SS & 3.722848 & Prob. Chi-Square(5) & 0.5900 \\
\hline \hline
\end{tabular}

Berdasarkan Tabel 6 terlihat bahwa nilai statsistik uji White bernilai 4,7978 dengan nilai prob sebesar 0,4410, karena nilai prob $>5 \%$ dapat disimpulkan $\mathrm{H}_{0}$ diterima, artinya asumsi homoskedastisitas terpenuhi atau tidak terdapat heteroskedastisitas. 
d. Uji Multikolinearitas

Metode yang digunakan untuk mendeteksi adanya multikolinearitas dalam penelitian ini dengan Variance Inflation Factor (VIF). Pengujian hipotesis sebagai berikut:

$\mathrm{H}_{0}$ : Tidak terjadi multikolinearitas dalam model

$\mathrm{H}_{1}$ : Terjadi multikolinearitas dalam model

Berdasarkan nilai VIF dari variabel yang signifikan, yaitu AKRA(-1) dan DIHSG diperoleh nilai VIF sebesar 1,029995 yang berarti VIF < 10. Dengan demikian, dapat disimpulkan terima $\mathrm{H}_{0}$ yang berarti tidak terjadi masalah multikolinearitas pada model.

\section{PENUTUP}

Berdasarkan hasil analisis dan pembahasan pada penelitian ini dapat disimpulkan bahwa estimasi model ADL pada data harga saham PT. AKR Corporindo Tbk dari periode Januari 2011 sampai dengan Desember 2016 dipengaruhi oleh nilai parameter, yaitu $\alpha=4,2880, \phi_{1}=0,9410$ dan $\beta_{0}=0,0081$. Hasil estimasi model ADL menunjukkan bahwa variabel harga saham suatu perusahaan dipengaruhi oleh harga saham itu sendiri pada satu bulan sebelumnya dan dipengaruhi oleh variabel IHSG pada bulan sekarang.

\section{DAFTAR PUSTAKA}

[1]. Widoatmodjo, S. Cara Sehat Investasi di Pasar Modal: Pengetahun Dasar. Jakarta: Jurnaliando Aksara Grafika; 2000.

[2]. Gujarati, D., \& Porter, D. C. Dasar-Dasar Ekonometrika. Jakarta: Selemba Empat; 2012.

[3]. Rosadi, D. Ekonomtrika dan Analisis Runtun Waktu Terapan dengan Eviews. Yogyakarta: Andi; 2012.

[4]. Islamiyahm, S. Penerapan Autoregressive Distributed Lag (ARDL) dalam Memodelkan Pengaruh Harga Minyak Dunia dan Jumlah Uang Beredar Terhadap Inflasi Di Indonesia. Jurnal Mahasiswa Statistik. 2013; 18(6): 45-48.

[5]. Apriyanto, D. Penerapan Autoregressive Distributed Lag (ARDL) untuk Pemodelan Harga Saham PT. Astra Internasional Tbk. Jurnal Mahasiswa Statistik. 2014; 24(8): 385-388.

UNY MINNA CHILIN

EVY SULISTIANINGSIH
: Jurusan Matematika FMIPA Untan, Pontianak, chilinminna@gmail.com

: Jurusan Matematika FMIPA Untan, Pontianak, evysulistianingsih@math.untan.ac.id

NAOMI NESSYANA DEBATARAJA : Jurusan Matematika FMIPA Untan, Pontianak, naominessyana@math.untan.ac.id 